\title{
6. Sınıf Öğrencilerinin Çizimlerinde Bitkilerin Büyüme ve Gelişmesine Etki Eden Faktörler
}

\section{Factors Affecting the Growthand Development of Plants in the Drawings of 6. Class Students*}

\begin{abstract}
Aslı ÖZTÜRK ${ }^{* *}$
Öz. Kavramlar fen öğretiminde önemli bir yer tutar. Fen eğitiminin amaçlarından biri, öğrencilerin bu kavramları ezberlemeden anlamlı olarak öğrenmelerini ve yaşantılarında gereksinimleri doğrultusunda kullanmalarını sağlamaktır. Kavram öğretimi yapılırken öğrencilerin kavram yanılgılarına sahip olup olmadıklarının dikkate alınması öğretimin verimliliğini arttırır. Öğrencilerin kavram hakkında neler anladıklarını, zihinlerinde nasıl canlandırdıklarını, kavram yanılgılarının olup olmadığını anlama tekniklerinden biri de çizimlerdir. Çizim, öğrencinin nasıl cevaplayacağı konusunda küçük sınırlamalar dışında sınırlama koymayan açık bir tekniktir. Çizimlerin amacı, öğretmenlerin diğer anlamayı inceleme yöntemleri ile ortaya çıkaramadığı durumların ortaya konulmasını da sağlamaktadır. Bu araştırmanın amacı, 6.sınıf öğrencilerinin fen bilimleri dersinde bitkilerin büyüme ve gelişmesine etki eden faktörler hakkındaki bilgilerini ve varsa kavram yanılgılarını çizimler aracılığıyla ortaya çıkarmaktır. Bu amaçla, 6. sınıf "Bitki ve Hayvanlarda Üreme, Büyüme ve Gelişme" ünitesinde ilgili kazanım işlenmeden önce ve sonra öğrencilerden bitkilerin büyümesine etki eden faktörleri çizim yoluyla anlatmaları istenmiştir. İkincil veri toplama kaynağını da öğrencilerle çizimleri hakkında yapılan bireyse görüşmeler oluşturmuştur. Araştırma grubu Sakarya ili, Hendek ilçesinde bulunan bir devlet ortaokulunda 6. sınıfta öğrenim görmekte olan 23 öğrenciden oluşmaktadır. Öğrencilerin çizimlerinde çoğunlukla su, güneş ve gübreye yer verdikleri, iki öğrencinin oksijeni de çizimlerine yansıttığı, ancak hiçbir öğrencinin karbondioksite yer vermediği görülmüştür. Sonuç olarak öğrencilerin bitkilerin büyüme ve gelişmesi için gerekli unsurlardan su ve ışığı çizimlerine yansıttıkları, ayrıca çizimlerde bazı kavram yanılgılarına da rastlandığ görülmüştür.
\end{abstract}

Anahtar Kelimeler: Bitkilerde büyüme ve gelişme, çizim tekniği, fen öğretimi, kavram öğretimi, kavram yanılgısı.

Abstract. Concepts have an important in science teaching. One of the aims of science education is to ensure that students learn meaningfully without memorizing these concepts and use them in their lives in accordance with their needs. Taking into account whether students have conceptual misconceptions when concept teaching is done, will increase the efficiency of teaching. One of the techniques to understand what students understand about concepts, how they reflect on their minds, and whether there are misconceptions is drawing. Drawing is an open technique that does not place limits on how the student will respond, except for small limitations. The purpose of drawings is also to provide the situations in which the teachers can not reveal the other meaning through the methods of examination. The aim of this research is to reveal the knowledge about the factors that influence the growth and development of plants in 6th grade students' science courses and if so, the misconceptions of the concepts through drawings. For this purpose, students were asked to describe the factors that affect the growth of plants, through drawings, before the 6th grade "Plant and Animal Reproduction, Growth and Development" unit was processed and after the unit was processed. But, individual interviews on student drawings set off secondary data collection source. There search group consists of 23 students who are studying in 6th grade in a state secondary school located in the province of Hendek in Sakarya province. It was seen that the students mostly included drawings of water, sun and fertilizer, two students reflected oxygen in their drawings, but no students had carbon dioxide. As a result, it confirmed that the students reflected on water and light their drawings from the elements necessary for growth of plants, and some misconceptions were found in drawings.

Keywords: Plant growth and development, drawing technique, science teaching, concept teaching, misconception.

\begin{tabular}{|c|}
\hline $\begin{array}{l}\text { Toplumsal Mesaj. } \\
\text { araştırmanın amacı, } 6 . \text { Bunı } \\
\text { öğrencilerinin fen bilimleri } \\
\text { dersinde bitkilerin büyüme ve } \\
\text { gelişmesine etki eden faktörler } \\
\text { hakkındaki bilgilerini ve varsa } \\
\text { kavram yanılgılarını çizimler } \\
\text { aracılığıyla ortaya çıkarmaktır. } \\
\text { Çalışma sonuçlarına göre } \\
\text { öğrencilerin bitkilerin büyüme ve } \\
\text { gelişmesi için gerekli unsurlardan } \\
\text { su ve ışığı çizimlerine yansıttıkları, } \\
\text { ayrıca çizimlerde bazı kavram } \\
\text { yanılgılarına da rastlandığı } \\
\text { görülmüştür. }\end{array}$ \\
\hline
\end{tabular}

Public Interest Statement.

The aim of this research is to reveal the knowledge about the factors that influence the growth and development of plants in 6th grade students' science courses and, if so, the misconceptions of the concepts through drawings. According to the results, it confirmed that the students reflected on water and light their drawings from the elements necessary for growth of plants, and some misconceptions were found in drawings.

\footnotetext{
* Bu çalışma VIII. Uluslararası Lisansüstü Eğitim Sempozyumunda bildiri olarak sunulmuştur.

** Sakarya Üniversitesi, Eğitim Bilimleri Enstitüsü, Fen Eğitimi Eğitimi Bölümü, aslioztt@gmail.com

*** Doç. Dr., Sakarya Üniversitesi, Eğitim Fakültesi, Matematik ve Fen Eğitimi Anabilim Dalı, aoztuna@sakarya.edu.tr 


\section{GíRiş}

Fen eğitimi, bireylerin bilimsel bilgileri bilme ve anlamasını, bilimsel süreçleri kullanmasını, hayal etme ve tasarımda bulunmasını, fen bilimlerine yönelik olumlu tutum geliştirmesini ve öğrendiklerini günlük yaşamda kullanma ve uygulamasını hedefler (Çepni, 2014). Doğal dünyadaki olgu ve olayları keşfetme ve açıklamada bilimsel fikirler kullanılmasının öğrenimini içeren fen eğitimi zor ve uzun vadeli bir süreçtir (Asoko, 2002). Bu süreç, küçük yaşlarda çocukların çevrelerine ilişkin naif gözlemleri ve doğrudan deneyimlemeleri ile informal olarak başlayıp okul sıralarında formal olarak devam eder.

Günlük yaşantımızda karşılaştı̆̆ımız yeni bilgileri, zihnimizde var olan bilgi yapılarıyla ilişkilendirerek öğrenme eğilimi, yaşam boyu süregelen bir olgudur. Bu öğrenme sürecinin gerçekleşmesinde kavramlar ise anahtar unsurları oluştururlar (Inel-Ekici, 2014). Kavramlar, zihnimizde anlamlanan farklı obje ve olguların değişebilen ortak özelliklerini temsil eden bir bilgi formu olup, anlam ağı kurmamızı, şemalar ve ilkeler geliştirmemizi sağlar. Böylece edinilen bilgileri sınıflandırarak zihnimizdeki var olan bilişsel yapılara yerleştirmemize ya da yeni bilişsel yapılar oluşturmamıza olanak tanırlar (Ülgen, 1996).

Öğrencilerin öğrendikleri bilgileri zihinlerinde doğru bir şekilde yapılandırabilmeleri için önceki bilgileri ile yeni bilgileri arasında ilişki kurabilmeleri gerekmektedir. Bu nedenle öğrencilerin ön bilgilerinin, varsa yanılgılarının tespit edilmesi ve giderilmeye çalışılması kavram öğretiminde önemli bir yer tutar. Çünkü birçok araştırma, çocukların formal fen eğitimi ile tanışmadan önce edindikleri naif düşüncelerinin gerçek bilimsel bilgilerden ne kadar uzak olabileceğine işaret etmektedir (Asoko, 2002; Driver, Asoko, Leach, Mortimer, Scott, 1994; Driver, Guesne ve Tiberghien, 1985; Treagust, Duit, Fraser, 1996). Bu sonuç doğal kabul edilmelidir. Çünkü doğrudan deneyimler fen öğrenme sürecinin her ne kadar önemli bir parçası olsa da, çocukların kendi başlarına keşfedecekleri şeylerin de bir sınırı olacaktır. Örneğin; bu araştırmanın da konusu olan bitkilerin büyüme ve gelişmesi ile ilgili olarak Loxley, Dawes, Nicholls ve Dore (2016) çocukların bitkilerin büyümesi için ışığa ve suya intiyaçlarının olduğunu sorgulayıcı yöntemlerle keşfedebileceklerini belirtmişlerdir. Bu bilgi, bitkilerin nasıl büyüdüğünün anlaşılmasında temel oluşturur. Ancak, ışık ve su olmadan bitkilerin neden yaşayamayacaklarının anlaşılması için bilimsel kabul edilmiş bir bilgi olan fotosentez sürecinin anlaşılması gerekmektedir. Bu ve buna benzer ön öğrenmelerinin eksik ya da yanlış olması sonraki öğrenmelerde de sorunlar yaratacaktır. Bu nedenle öğretmenlerin, öğrencilerin dersle ilgili ön öğrenmelerini kontrol edip tamamladıktan sonra yeni öğrenmelere geçmesi oldukça önemlidir. Aksi takdirde eksik ve yanlış öğrenmeler zincirleme bir şekilde devam edecektir (Senemoğlu, 2003).

Kavram öğretiminde ve öğrencilerin sahip olduğu ön bilgileri ortaya çıkarmada kullanılan teknikler arasında kavram haritaları, zihin haritaları, kavram ağları, anlam çözümleme tabloları, V diyagramları, tahmin-gözlem-açıklama, kavramlar ve olaylar hakkında görüşme, çizimler, kelime ilişkilendirme sayılabilir (Karamustafaoğlu, Karamustafaoğlu, Yaman, 2005). Taber de (1999) benzer şekilde ön bilgilerin ortaya çıkarılmasında ve kavram yanılgılarının teşhis edilmesinde görüşme, anlam çözümleme tablosu, grup tartışmaları, kavram haritaları, çizim ve yazılı sondajlamaları önermektedir. Bu çalışmada öğrencilerin bitkilerin büyüme ve gelişmesine etki eden faktörler hakkındaki düşüncelerini ortaya çıkarmak için çizim tekniği kullanıımıştır.

Çizim, öğrenciye küçük sınırlamalar dışında sınırlama koymayan açık uçlu bir teknik olup anlamanın birçok boyutunu ortaya koyabilir. Çizim yapma çoğu insan tarafından eğlenceli bulunan gerçek içerik ve davranışları yansıtan bir aktivitedir. Çizimler, öğrencilerin kendi öğrenmelerini yansıtmalarına, öğretmenlerin de öğrenmeyi planlamalarına imkan tanır (Atasoy, 2004). Bununla birlikte, öğrencilerin fen konuları hakkındaki alternatif düşünceleri de çizim yoluyla ortaya çıkarılabilir. Çizim, öğrencilerin yanlış kavramalarını teşhis etmek amacıyla kullanılabileceği gibi sınıf etkinliği olarak da kullanılabilen bir tekniktir (Taber, 1999). Nitekim farklı fen kavramlarında ve farklı seviyelerde bireylerle yapılan bir çok araştırmada -insan vücudu (Patrick, Tunnicliffe, 2010), insan organları ve sistemler (Reiss, Tunnicliffe, 2001), sindirim sistemi (Çardak, 2015; Şaşmaz-Ören, 
Ormancı, 2014), çiçeğin yapısı ve bitki hücresi (Umdu-Topsakal, Oversby, 2012), böceklerin yaşam döngüsü ve yaşam şekilleri (Çinici, 2013), hücre (Yörek, 2007), çevre ve çevre bilinci (Yavuz, BalkanıKıyıcı, Atabek-Yiğit, 2015), madde (Ormancı, Balım, 2014), Newton kanunları (Uzunkavak, 2009), ışık (Kara, Erduran-Avcı, Çekbaş, 2008)- çizim tekniği kullanılmıştır. Bu çalışmada da bitkilerin büyüme ve gelişmelerine etki eden faktörler konu edinilmiş ve çizim yoluyla bu konu hakkında öğrencilerin ön bilgileri ve yanlış kavramaları tespit edilmeye çalışılmıştır. Öğrencilerin doğal çevrenin yoğun olduğu bir ortamda yaşamaları ve çevrelerinde tarımla uğraşan bireylerin olması sebebiyle bitkilerin büyüme ve gelişmelerinin günlük hayatlarında çokça gözlemledikleri bir fen olgusu olması bu konuya odaklanılmasının sebebi olmuştur.

\subsection{Amaç}

Çalışmada, 6.sınıf öğrencilerinin bitkilerin büyüme ve gelişmesine etki eden faktörler hakkındaki düşüncelerini çizimler aracılı̆̆ıla ortaya çıkarmak amaçlanmıştır. Bu amaçla aşağıdaki alt problemlere cevap aranmıştır:

1) Öğrencilerinin çizimlerinde ilgili konu işlenmeden önde bitkilerin büyüme ve gelişmesine etki eden faktörler nelerdir?

2) İlgili konu işlendikten sonra bitkilerin büyüme ve gelişmesine etki eden faktörler öğrencilerin çizimlerine nasıl yansımıştır?

3) 6. sınıf öğrencilerinin bitkilerin büyüme ve gelişmesine etki eden faktörlerle ilgili hatalı ve/veya yanlış kavramaları nelerdir?

\section{YÖNTEM}

\subsection{Araştırma Modeli}

Bu araştırmada, nitel araştırma yöntemlerinden biri olan fenomenolojik desen kullanılmıştır. Fenomenoloji, kolay kolay yüzeye çıkmayan karmaşık bir sorunun, bir başka deyişle "gerçeğin", ortaya çıkartılmasına yönelik bir süreçtir. Bireysel evrenin araştırılması fenomenolojinin konusunu oluşturur, odağı ise bireysel tecrübelerdir. Araştırmacı katılımcının kişisel (öznel) tecrübeleri ile ilgilenir, bireylerin algılamalarını ve olaylara yükledikleri anlamları inceler (Baş ve Akturan, 2008). Creswell'e (2013) göre ise fenomenoloji birkaç birey tarafından deneyimlenen bir fenomenin derinlemesine anlaşıımasını sağlamaktadır. Bu çalışmada da öğrencilerin bitkilerin büyüme ve gelişmesine etki eden faktörler hakkındaki düşünceleri ortaya çıkarılmaya çalışılmıştır. Günlük hayatta gözlemledikleri ve tecrübe ettikleri bu olguyu kendi tecrübelerinden yola çıkarak nasıl açıkladıkları çizim ve görüşmeler yoluyla sondalanmıştır.

\subsection{Araştırma Grubu}

Araştırma grubu uygun örnekleme yolu ile belirlenmiştir. Araştırmacılardan birinin fen bilimleri öğretmeni olarak dersine girdiği 6. sınıf araştırma grubu olarak seçilmiştir. Araştırma grubunu 2016-2017 eğitim-öğretim yılında Sakarya ili Hendek ilçesinde bulunan bir devlet ortaokulunda 6. sınıfta öğrenim görmekte olan 23 öğrenci oluşturmaktadır. Bu öğrencilerden 10'u kız, 13'ü erkektir.

\subsection{Veri Toplama Araçları ve Verilerin Analizi}

Araştırma kapsamında birincil veri toplama kaynağını öğrencilerin çizimleri oluşturmuştur. Birinci uygulamada (Bitki ve hayvanlarda üreme, büyüme ve gelişme ünitesindeki "6.5.1.3. Bitki ve hayvanlarda büyüme ve gelişmeye etki eden faktörleri açıklar." kazanımı işlenmeden önce) Ek 1'de yer alan görsel ve soru resim kağıtlarına basılarak öğrencilere verilmiştir. Kendilerinden istenen çizimi resim kağıdının altından boş kalan alana ya da resim kağıdının arkasına içlerinden geldiği şekilde sınırlama koymaksızın (görsellerin yanı sıra yazıların da yer alabileceği, dilerlerse karikatürize edebilecekleri vb. söylenerek) resmetmeleri istenmiştir. Konu öğretim programının öngördüğü şekilde işlendikten sonra yine resim kağıtlarına daha açık uçlu olarak "Bir bitkinin büyüme ve gelişmesine etki eden faktörleri çizim yaparak gösteriniz. Çizdiğiniz resme bir isim koyunuz." Sorusu basılarak öğrencilere verilmiş, aynı şekilde serbest bırakılarak çizim yapmaları istenmiştir. Çizim 
esnasında araştırmacılar öğrencilere çeşitli formda ve renkte kalemler sağlamışlardır. Resimler içerik analizine tabi tutulmuştur. Her bir çizimde yer alan unsurlar, resmedilen mekan araştırmacılar tarafından ayrı ayrı kodlanmış, ardından bu kodlamalar karşılaştırılmıştır.

Ikincil veri toplama kaynağı olarak ise öğrencilerin çizimleri incelendikten sonra her bir öğrencinin çizimleri üzerinden oluşturulan yarı yapılandırılmış görüşmeler kullanılmıştır. Araştırmacılar resimleri inceledikten sonra anlaşılmayan noktalara ilişkin her bir öğrencinin resimlerinden yola çıkarak hazırladıkları yarı yapılandııılmış görüşme sorularıyla 17 öğrenci ile bireysel görüşmeler yapmışırı. Böylece öğrencilerin çizimlerinde yer alan unsurlar aydınlatılmıştır.

Öğrencilerin isimlerinin saklı tutulması için kodlamalar yapılmıştır. Numara sırasına sokulan öğrencilerin her biri cinsiyetlerini temsilen $\mathrm{K}(\mathrm{k} \mathrm{z})$ ya da $\mathrm{E}$ (erkek) sıralarını temsilen 1'den 23'kadar "E1, E2..., K1, K2..." şeklinde numaralandırılmıştır.

\section{BULGULAR}

Araştırmanın bulguları, ilgili kazanım işlenmeden önce öğrencilerin bitkilerin büyüme ve gelişmesine etki eden faktörleri çizimlerine nasıl yansıttıkları, kazanım işlendikten sonra çizimlerinden elde edilen kodlamalar ve araştırma sürecinde konu ile ilgili ortaya çıkan yanlış kavramalar olmak üzere üç başlık altında toplanarak değerlendirilmiştir.

\section{1 Öğrencilerin bitkilerin büyüme ve gelişmesine etki eden faktörlere ilişkin ilk çizimlerine yönelik bulgular}

Öğrencilerin bitkilerin büyüme ve gelişmesine etki eden faktörlere ilişkin konu işlenmeden önceki çizimlerine ait kodlamalar Tablo 1'de sunulmuştur.

Tablo 1. Öğrencilerin konu işlenmeden önceki çizimlerinden elde edilen kodlamalar

\begin{tabular}{ll}
\hline Kodlamalar & Sıklık \\
\hline Su & 23 \\
Güneş & 20 \\
Gübre & 16 \\
Toprak & 11 \\
Insan & 5 \\
Hücre & 3 \\
Oksijen & 2 \\
Temiz hava & 2 \\
Mikrop & 2 \\
Tohum & 1 \\
Solucan & 1 \\
\hline
\end{tabular}

Çalışmaya katılan 23 öğrencinin hepsinin çizimlerinde suya yer verdikleri görülmektedir. Bu öğrencilerden altısı su kaynağı olarak yağmuru resmederken 13 tanesi sulama, dört öğrenci ise hem yağmur hem sulamayı resimlerine yansıtmıştır. 20 öğrenci bitkilerin büyüme ve gelişmesine etki eden faktörlerden ışık kaynağı olarak güneşe yer vermiştir. Fakat bu öğrencilerle yapılan görüşmelerde bazılarının üç öğrencinin (E5, E11, K10) güneşi enerji kaynağı olarak ele almadığı, bitkilerin güneşten $D$ vitamini almak için faydalandıkları ortaya çıkmıştır.

Çizimlerde yer alan diğer unsurlara bakıldığında yoğun olarak (16 sıklıkla) gübrenin karşımıza çıktığı görülmektedir. Bu çizimlerin dokuzu doğal gübre, yedisi yapay gübredir. 11 öğrencinin çiziminde ise toprak da vurgulanarak çizimlerinde yer almıştır. Bunların dışında iki öğrenci oksijen, iki öğrenci de temiz havayı resmetmişlerdir. Ancak kendileriyle yapılan görüşmelerde temiz havadan kastettiklerinin oksijen olmadığı tespit edildiğinden ayrı ayrı kodlanmıştır. Ayrıca çizimlerdeki hücre, mikrop, tohum, solucan ve insan resimleri yanlış kavramalar olarak karşımıza çıkmaktadır. Resimlerinde insana yer veren öğrencilerle (E3, E4, K1, K9) yapılan görüşmelerde bu görselle insanın bitkiye olan ilgisinin kastedildiği anlaşılmıştır. Aşağıda öğrencilerin çizimlerinden örneklere yer verilmiştir. 


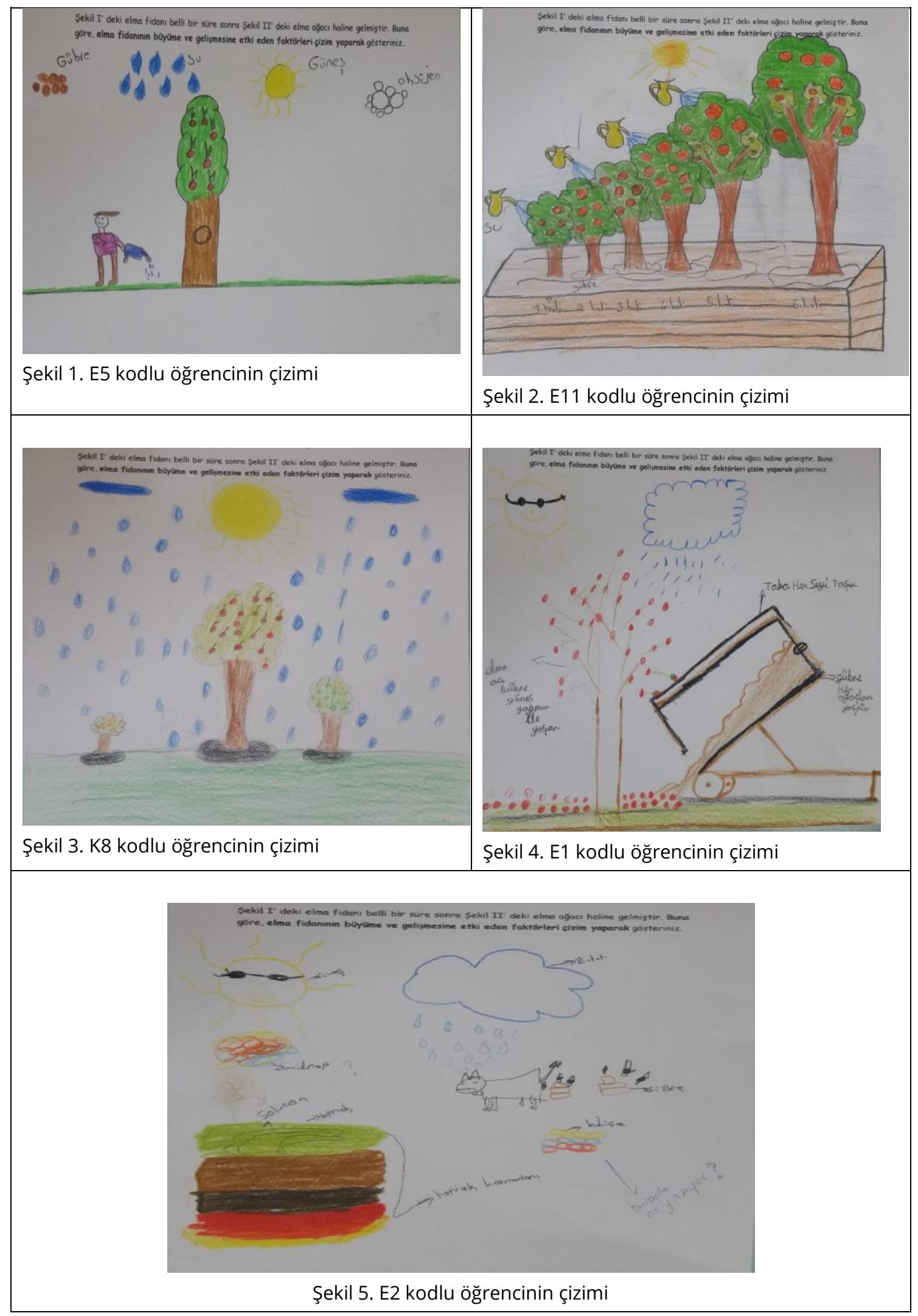


Örnek çizimlerin hepsinde bitkilerin büyüme ve gelişmesinde önemli bir yere sahip olan su ve güneşe yer verildiği görülmektedir. Bazı resimlerde bitkilerin su ihtiyaçlarının doğal yolların yanı sıra insanlar tarafından da karşılandığına ilişkin çizimler yer almaktadır. E5, E1 ve E2 kodlu öğrencilerin çizimlerinde gübreyi de bitkilerin büyüme ve gelişmesine etki eden faktörler arasında yer verdikleri görülmektedir. Sadece E5 kodlu öğrenci diğerlerinden farklı olarak oksijeni de resmetmiştir. Tablo 1'den de görüleceği üzere E5 kodlu öğrencinin dışında bir öğrenci daha oksijeni resmine yansıtmıştır. Kendileri ile yapılan görüşmede oksijeni karbondioksitle karıştırıp karıştırmadıkları anlaşılmaya çalışılmış ve karbondioksiti kastetmedikleri oksijene intiyaçları olduğunu düşündükleri ortaya çıkarılmıştır. Bu öğrencilerin dışında iki öğrenci de çizimlerinde temiz havaya yer vermişlerdir. E2 kodlu öğrencinin çiziminde ayrıca mikrop, solucan ve hücre gibi bir bitkinin büyüme ve gelişmesi için gerekli olmayan unsurları da ele aldığı görülmektedir.

\section{2.Öğrencilerin konu işlendikten sonraki çizimlerine ilişkin bulgular}

ilk çizimlerin ardından konu, müfredatın gerektirdiği şekilde işlenmiş ve ardından öğrencilerden yeniden çizim yapılması istenmiş ve çizimlerden elde edilen kodlamalar Tablo 2'de yansıtılmıştır.

Tablo 2. Öğrencilerin konu işlendikten sonraki çizimlerinden elde edilen kodlamalar

\begin{tabular}{lc}
\hline Kodlamalar & Sıklık \\
\hline Su & 19 \\
Güneş & 19 \\
Gübre & 14 \\
Oksijen & 6 \\
Toprak & 3 \\
Hücre & 2 \\
Insan & 2 \\
Mikroplar & 1 \\
Tohum & 1 \\
Kök & 1 \\
Karbondioksit & 1 \\
\hline
\end{tabular}

Konu işlendikten sonra yapılan ikinci çizimler incelendiğinde su ve güneşin yine ön sıralarda olduğu görülmektedir. Çizimlerinde suya yer veren öğrencilerden $11^{\prime} \mathrm{i}$ yağmuru su kaynağı olarak resmederken, altısı sulama, ikisi ise hem yağmur hem de sulamayı resmetmiştir. Güneş resminin ikinci uygulamada azaldığı görülmektedir. 23 öğrenciden 19'u güneşi resmetmiştir. Yapılan görüşmelerde iki öğrenci bitkilerin, güneşin $D$ vitamininden faydalandığını söylemiştir. 14 öğrenci bitkinin büyüyebilmesi için gübrenin gerekli olduğunu da vurgulayan resimler çizmişler, bunlardan yedisi doğal, yedisi ise yapay gübreye yer vermişlerdir. Altı öğrenci oksijen olmadan bitkilerin yaşayamayacağını belirtmiştir. Çizilen diğer unsurlara baktığımızda da yine ilk çizimlerde olduğu gibi toprak, hücre, insan, mikroplar, tohum ve kök çizilmiştir. illk çizimlerden farklı olarak ise sadece bir öğrenci bitkilerin büyüyüp gelişebilmesi için karbondioksite intiyaç olduğunu belirtmiştir. İlgili çizimlerden örneklere aşağıda yer verilmiştir. 


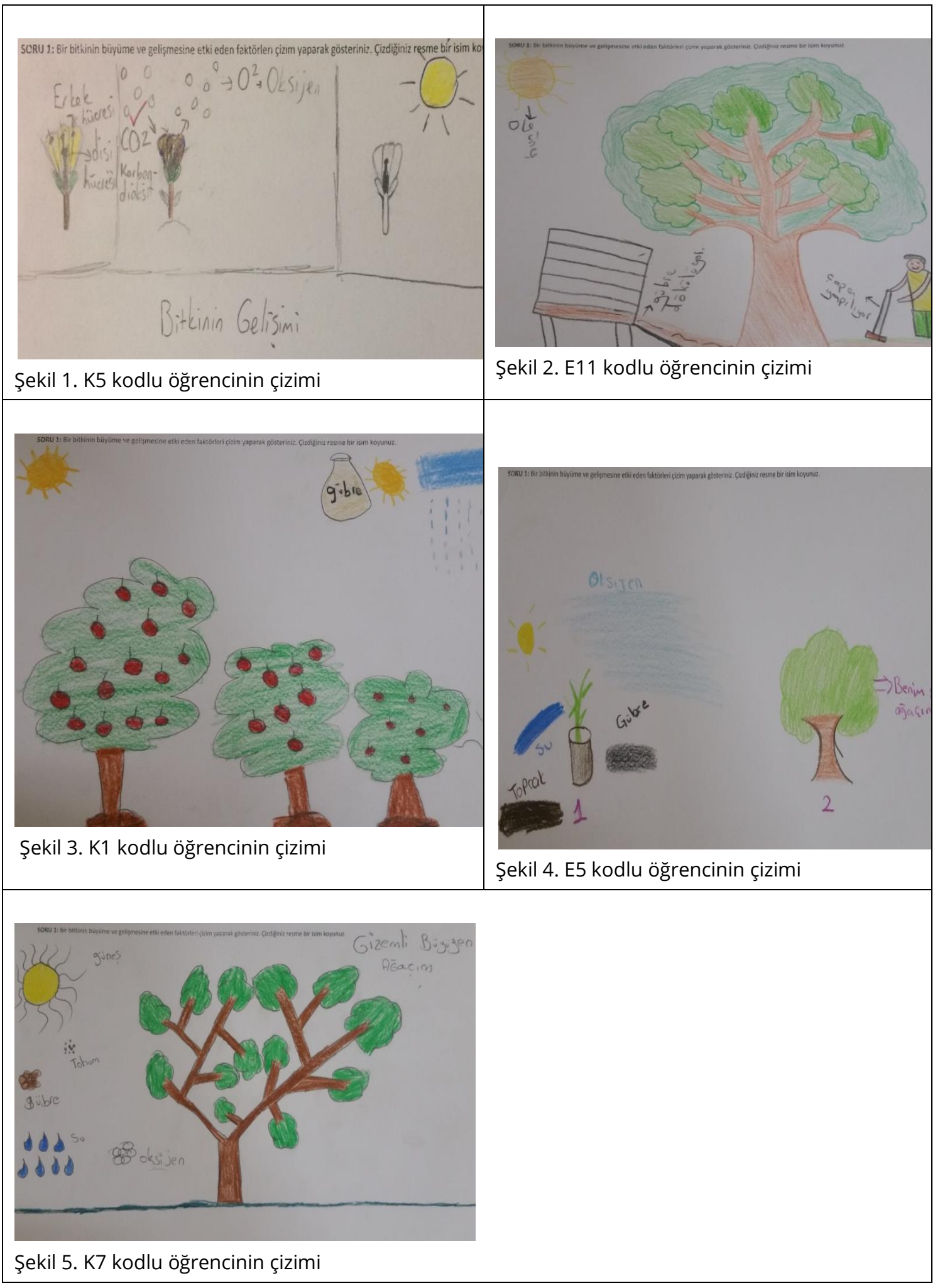


Tablo 2'deki kodlamalar ve örnek resimler incelendiğinde öğrencilerin konu işlendikten sonra da hemen hemen aynı çizimlere yer verdikleri görülmektedir. Su, güneş ve gübre çizimlerde ön plana çıkmaktadır. K5'in çiziminde resmettiği çiçeğin kısımlarını da göstermesi ilgili ünitedeki diğer kazanımların bir yansıması olarak görülebilir.

\subsection{Araştırma Kapsamında Ortaya Çıkan Yanlış Kavramalar}

Araştırma kapsamında gerek ön uygulamada gerekse son uygulamada öğrencilerin çizimlerinde yanlış kavramalardan kaynaklanan bazı düşüncelerin yer aldığı görülmüştür. Bu düşünceler aşağıda ifade edilmiştir:

- Bitkilerin güneșten D vitamini almak için faydalandıkları düşüncesi (E5, E11, K10)

- Bitkilerin büyüme ve gelişmesi için oksijene/temiz havaya ihtiyaç duymaları (E5, E9, K7)

- Bitkilerin büyüme ve gelişmesine etki eden ilgisiz faktörlerin olduğunu düşünme: hücre, insan, tohum, mikrop, solucan vb. (E2, E6)

\section{TARTIŞMA, SONUÇ VE ÖNERILER}

Araştırmada 6. sınıf öğrencilerinin bitkilerin büyüme ve gelişmesine etki eden faktörlere yönelik bilgileri çizim tekniği ile ortaya çıkarılmıştır. Bu amaçla ilgili konu işlenmeden önce ve sonra öğrencilerden çizim yapmaları istenmiştir. İlk uygulamada öğrencilerin çizimlerinde bitkilerin büyüme ve gelişmesine etki eden faktörlerden yoğunluklu olarak su, güneş ve gübreye yer verdikleri görülmüştür. Çalışmaya katılan öğrencilerin tümünün çizimlerinde yer alan suyun kaynağı bazı öğrencilerde doğal bazı öğrencilerde sulama şeklinde resmedilmiştir. Bitkilerin büyüme ve gelişmesi için su ve nemlilik, ışık kaynağı olarak da güneş önemli bir unsurdur. Öğrencilerin çoğunun ilk çizimlerinde bu unsurlara yer vermeleri güzel bir sonuçtur. Çizimlerinde gübrelemeye yer veren öğrencilerle yapılan bireysel görüşmelerde gübrenin bitkinin büyüme ve gelişmesinde neden faydalı ya da etkili olduğuna ilişkin bir açıklama gelmemiştir. Görüşmelerden elde edilen veriler doğrultusunda öğrencilerin gübrelemeyi çevrelerinde bahçe ile uğraşan yakınlarından gördükleri için çizimlerine yansıttıkları ortaya çıkarılmıştır.

Bitkilerin büyüme ve gelişmesinde etkili olan faktörlerin en önemlilerinden biri de karbondioksittir. Ancak konu işlenmeden önce yapılan hiçbir çizimde değinilmeyen karbondioksite, konu işlendikten sonra yapılan çizimlerde de sadece bir öğrenci tarafından değinilmiştir. Bu durum Loxley, Dawes, Nicholls ve Dore'un da (2016) belirttiği gibi, öğrencilerin bitkilerin büyüme ve gelişmesinde ışığa ve suya ihtiyaç duyduklarını, sorgulayıcı yöntemlerle kendilerinin keşfettiklerinin bir göstergesi olabilir. Öte yandan bilimsel bir bilgi olarak fotosentez sürecinin anlaşılması daha zor bir bilişsel süreç olarak kabul edilebilir. Çünkü öğrencilerin konu işlendikten sonraki çizimlerinde de bir öğrencinin dışında, bitkilerin kendi besinlerini üretmek için ışık kaynağı ve su kadar karbondioksite de ihtiyaç duyduklarını gösteren herhangi bir görsel ya da ifadeye rastlanmamıştır. Nurbaety, Rustaman ve Sanjaya'nın (2015) 32 sekizinci sınıf öğrencisi ile yaptığı araştırmalarında da benzer şekilde öğrencilerin fotosentezle ilgili kısmi düzeyde anlamaya ve çeşitli yanlış anlamalara sahip oldukları ortaya çıkarılmıştır. illgili araştırmada da çizimlerin \%70'e yakın kısmında ışık kaynağı olarak güneşin resmedildiği görülmüştür. Bu çalışmada da 23 öğrenciden 20'si ışık kaynağı olarak güneşi resmetmiştir.

Öğrencilerin çizimlerinde insan, solucan, mikrop, tohum gibi ilgisiz veya yanlış kavramaların yol açtığı unsurlara da yer verdikleri dikkat çekmektedir. Resimlerinde ilgisiz faktörler olarak en çok insana yer verilmiştir. Çizimlerinde insana yer veren öğrencilerle yapılan görüşmelerde, insana yer verilmesinin nedeni olarak bitkilere ilgi göstermeleri ileri sürülmüştür. Benzer bulgulara Christdiou ve Hatzinitika'nın (2005) okul öncesi dönemdeki çocuklarla yaptığı çalışmada da rastlanmıştır. Çocukların büyük bir kısmı, bitkilerin büyüme ve gelişmesi için temel faktörün insan olduğunu 
düşünmektedirler. Her ne kadar bu araştırmada insan faktörünü bitkinin büyüme ve gelişmesinde önemli bir unsur olarak gören öğrenci sayısı az da olsa halen bu düşüncenin var olması önemli bir bulgudur. Öte yandan ilk uygulamada beş öğrenci tarafından insan figürü resmedilirken ikinci uygulamada bu sayının ikiye düşmesi de önemli bir gelişme olarak kabul edilebilir.

Araştırma kapsamında öğrencilerden bazılarının konu ile ilgili iki yanılgıya da sahip oldukları ortaya çıkarılmıştır. Bunlardan biri bitkilerin güneşten D vitamini almak için faydalandıkları, diğeri ise büyüme ve gelişmeleri için oksijene/temiz havaya ihtiyaç duymalarıdır. Öğrencilerle yapılan görüşmelerde oksijeni çizimlerine yansıtan öğrencilerin fotosentez yapmak için oksijene ihtiyaç duydukları yani karbondioksitin yerine oksijeni koydukları ortaya çıkmıştır. Öğrencilerin fotosentez ile solunumu birbiriyle karıştırdıkları, bu konularda yeteri kadar bilgi sahibi olmadıkları söylenebilir. Bu bulgu, seviye olarak daha üst düzeylerde dahi görülen bir durumdur. Örneğin, Köse'nin (2008) üniversite öğrencileriyle gerçekleştirdiği çalışmasında aynı şekilde mülakatlarla desteklenen çizim tekniği kullanılmış ve bazı öğrencilerin bitkilerde fotosentez ve solunuma ilişkin kavram yanılgılarına sahip oldukları ortaya çıkarılmıştır.

Mülakatlarla desteklenen çizim tekniği ile öğrencilerin bilgi düzeyleri kadar kavram yanılgılarının da tespit edilebileceği görülmüştür. Nitekim farklı konuların ele alındığı ve çeşitli düzeylerde çizimlerin kullanıldığı birçok araştırmada da kavram yanılgıları ortaya çıkarılmıştır. Taştan-Kırık ve Kaya (2014) 6. sınıf öğrencileri ile yürüttükleri araştırmalarında öğrencilerin hücre çizimlerinde çok sayıda alternatif kavramaya rastladıklarını ifade etmektedirler. Aynı şekilde hücre konusunu 9. ve 11. sınıflarla çizim tekniğini kullanarak çalışan Yörek de (2007) araştırmasında yanlış kavramaları ortaya koyduğuna vurgu yapmaktadır. Çardak (2015), öğretmen adayları ile yaptığı araştırmada sindirim sistemi ile ilgili yanlış kavramaları çizim tekniği ile ortaya çıkarırken, Uzunkavak (2009) iş konusunda üniversite öğrencilerinin yanılgılarını çizim yoluyla tespit etmiştir. Çizim tekniğini kullanan bir diğer araştırmada Nakiboğlu (2003) üniversite öğrencilerinin atomla ilgili bazı yanlış anlamalara sahip olduğunu göstermiştir. Söz konusu araştırmalar göz önünde bulundurulduğunda ve bu araştırmanın sonuçları da dikkate alındığında çizim tekniğinin öğrencilerin bilgi ve düşüncelerinin, kavram yanılgılarının ortaya çıkarılmasında önemli bir yerinin olduğu söylenebilir. Ortaokul öğrencileri ile çalışan Ormancı ve Balım da (2014) çizim tekniğinin öğrenci fikirlerini belirlemede etkili bir teknik olduğunu ifade etmektedirler. Öte yandan çizimler tek başına kullanıldığında yetersiz ya da eksik bilgi vereceği durumların oluşabileceği de görülmüştür. Örneğin; çizimlerinde güneşe yer veren bazı öğrencilerin güneşten bitkilerin D vitamini almak için faydalandıkları düşüncesi ancak görüşmeler yoluyla ortaya çıkarılmışır. Her ne kadar araştırmada birincil veri kaynağı olarak çizimler kullanılmış olsa da anlaşılmayan hususların aydınlatılmasında görüşmeler kullanılmış ve böylelikle öğrencilerin çizimlerine yükledikleri anlamlar daha net bir şekilde ortaya koyulmuştur. Bu sebeple çizimlerin tek başına kullanılmaması, görüşmeler ya da yazılarla desteklenmesi önerilmektedir. Aksi takdirde yanlış ya da eksik anlamalara sebep olabilir.

İlgili kazanımlar işlendikten sonra da öğrencilerin çizimlerinde bir öğrenci hariç herhangi bir değişim ya da gelişme olmadığı gözlenmiştir. Araştırma deneysel bir çalışma olmadığından dersler müfredatın ön gördüğü şekilde ekstra bir uygulama gerçekleştirilmeden yapılmıştır. Buna karşııık öğrencilerin konuyu yeteri kadar kavrayamadıkları, konunun işlenmesi sırasında fotosentez ile bitkilerin gelişimi arasında ilişkilendirme yapamadıkları, yanılgısı olanların yanılgılarının devam ettiği görülmüştür. Bu durum kavram yanılgılarının dirençli yapısına bağlanabilir (Campanario, 2002; Driver, 1989; Harlen, 1993; Treagust, Duit \& Fraser, 1996).

Sonuç olarak çizim tekniğinin öğrencilerin konu hakkındaki bilgi düzeylerini, düşüncelerini, kavramlar arasında kurdukları ilişkileri ve kavram yanılgılarını anlamada rahatlıkla kullanılabilecek bir teknik olduğu söylenebilir. Ancak çizime yansıtılamayan unsurların aydınlatılması için mutlaka görüşme, açık uçlu sorular vb. tekniklerle desteklenmesi önerilmektedir. Öğretim esnasında da öğrencilerin konu işlenmeden önceki çizimleri üzerinden derslerin şekillendirilmesi, öğrencilerin çizimleri ile derste öğrendiklerini karşılaştırmalarına fırsat verilmesi sağlanmalıdır. Çünkü bu araştırmada çizimler sadece konunun başında ve sonunda veri toplama aracı olarak kullanılmıştır 
ve ikinci uygulamada herhangi bir değişiklik oluşmamıştır. Eğer çocukların çizimleri konu işlenirken kullanılmış olsaydı, hata ve eksikliklerini kendi çizimleri üzerinden görebilecekleri bir ortam yaratılabilir, böylece öğrencilerin çizimleri birer öğretim materyali halini alır ve kendi çizimleri üzerinden öğrenmelerini kontrol etmeleri sağlanabilir.

\section{Kaynakça}

Asoko, H. (2002). Developing conceptual understanding in primary science. Cambridge Journal of Education. 32(2), 153-164. doi: 10.1080/03057640220147522

Atasoy, B. (2004). Fen Öğrenimi ve Öğretimi. Ankara: Asil Yayın Dağıtım.

Baş, T. ve Akturan, U. (2008). Nitel Araştırma Yöntemleri. Ankara: Seçkin Yayıncılık.

Campanario, J. M. (2002). The parallelism between scientists' and students' resistance to new scientific ideas. International Journal of Science Education, 24(10), 1095-1110.

Christdiou, V. ve Hatzinikita, V. (2005). Preschool children's explanations of plant growth and rainformation: A comparative analysis. Research in Science Education. 35, 471-495.

Creswell, J. W. (2013). Nitel Araştırma Yöntemleri. Ankara: Siyasal Kitabevi.

Çardak, O. (2015). Student science teachers' ideas of the digestive system. Journal of Education and Training Studies. 3(5). doi: 10.11114/jets.v3i5.912. http://dx.doi.org/10.11114/jets.v3i5.912.

Çepni, S. (2014). Kuramdan Uygulamaya Fen ve Teknoloji Öğretimi. Ankara: PegemA Yayıncılık.

Çinici, A. (2013). From caterpillar to butterfly: A window for looking into students' Ideas about life cycle and life forms of Insects. Journal of Biological Education, 47(2), 84-95. DOI: 10.1080/00219226.2013.773361.

Driver, R. (1989). Students' conceptions and the learning of science. International Journal of Science Education, 11, Special Issue, 481-490.

Driver, R., Asoko, H., Leach, J., Mortimer, E. ve Scott, P. (1994). Constructing scientific knowledge in the classroom. Educational Researcher. 23(7), 5-12.

Driver, R., Guesne, E. ve Tiberghien, A. (Eds.). (1985). Children's Ideas in Science. Philadelphia: Open UniversityPress.

Harlen, W. (1993). Teaching and Learning Primary Science. London: Paul Chapman Publishing Ltd.

İnel-Ekici, D. (2014). Kavram Öğretimi. Fen Bilimleri Öğretimi içinde (Ed. Ş.S. Anagün, N. Budan) Ankara: Anı Yayıncılık.

Kara, İ., Erduran-Avcı, D. ve Çekbaş, Y. (2008). Fen bilgisi öğretmen adaylarının ışık kavramı ile ilgili bilgi düzeylerinin araştırılması. Mehmet Akif Ersoy Üniversitesi Eğitim Fakültesi Dergisi.

Karamustafaoğlu, S., Karamustafaoğlu, O. ve Yaman, S. (2005). Fen ve Teknoloji Eğitiminde Kavram Öğretimi. M. Aydoğdu, T. Kesercioğlu (Ed.), ilköğretimde fen ve teknoloji öğretimi (25-54). Ankara: Anı Yayıncılık.

Köse, S. (2008). Diagnosing student misconceptions: using drawings as a research method. World Applied Sciences Journal. 3(2), 283-293.

Loxley, P., Dawes, L., Nicholls, L. ve Dore, B. (2016). ilköğretimde eğlendiren ve anlamayı geliştiren fen öğretimi. (H. Türkmen, M. Sağlam, E. Şahin-Pekmez, çev.) Ankara: Nobel Yayınevi.

Nakiboğlu, C. (2003). Instructional misconceptions of Turkish preopective chemistry teachers about atomic orbitals and hybridization. Chemstry Eucation: Research an Practice. 4(2), 171-188.

Nurbaety, D., Rustaman, N. Y. ve Sanjaya, Y. (2015). The use of drawing method for diagnosing students' misconception about plant structure in relation to photosynthesis. Proceedings of International Seminar on Mathematics, Science, and Computer Science Education (MSCEIS 2015) AIP Conf. Proc. doi: 10.1063/1.4941192

Ormancı, Ü. ve Balım, A. G. (2014). Ortaokul öğrencilerinin madde konusuna yönelik fikirleri: çizim yöntemi. Elementary Education Online, 13(3), 827-846. 
Patrick, P. G. ve Tunnicliffe, S. D. (2010). Science teachers' drawings of what is inside the human body. Journal of Biological Education. 44(2), 81-87.

Reiss, M.J. \& Tunnicliffe, S.D. (2001). Student's understandings of human organs and organ systems. Research in Science Education. 31, 383-399.

Senemoğlu, N. (2003). Gelişim, öğrenme ve öğretim kuramdan uygulamaya. Ankara: Gazi Kitabevi

Şaşmaz-Ören, F. ve Ormancı, Ü. (2014). Exploring pre-service teachers' ideas about the digestive system by using the drawing method. Journal of Baltic Science Education. 13, 1648-3898.

Taber, K. S. (1999). Probing understanding. Cambridge: The learning Company Inc.

Taştan-Kırık, Ö., Kaya, H. (2014). A qualitative study concerning the 6th grade students' conceptual structures about the cell concept. International Online Journal of Educational Sciences. 6(3), 737760.

Treagust, D. F., Duit, R. ve Fraser, B. J. (1996). (eds.). Improving Teaching and Learning in Science and Mathematics. New York: Teachers College Press.

Treagust, D.F., Duit, R. ve Fraser, B. (1996). Improving teaching and learning in science and mathematics. New York: Teachers College Press.

Umdu-Topsakal, U. ve Oversby, J. (2012). Turkish student teachers' ideas about diagrams of a flower and a plant cell. Journal of Biological Education. 46(2), 81-92.

Uzunkavak, M. (2009). Öğrencilerin Newton kanunları bilgilerinin yazı ve çizim metoduyla karşıllaştırılması. SDU International Journal of Technologic Sciences. 1(1), 29-40.

Ülgen, G. (1996). Kavram Geliştirme, Kuramlar ve Uygulamalar. Ankara: Setma Basımevi.

Yavuz, M., Balkanı-Kıyıcı, F. ve Atabek-Yiğit, E. (2015). Ortaokul öğrencilerinin çevre ve çevre bilinci algısının çizim yöntemi ile incelenmesi. VI. Uluslararası Türkiye Eğitim Araştırmaları Kongre Tam Metin Bildirileri Kitabı, 1264-1272.

Yörek, N. (2007). Öğrenci çizimleri yoluyla 9 ve 11. Sınıf öğrencilerinin hücre konusunda kavramsal anlama düzeylerinin belirlenmesi. Dokuz Eylül Üniversitesi Buca Eğitim Fakültesi Dergisi, 22, $107-$ 114. 
Ek 1. Konu işlenmeden önce öğrencilerden istenen çizim formu

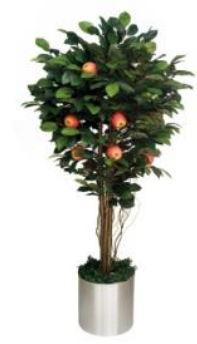

Şekil I

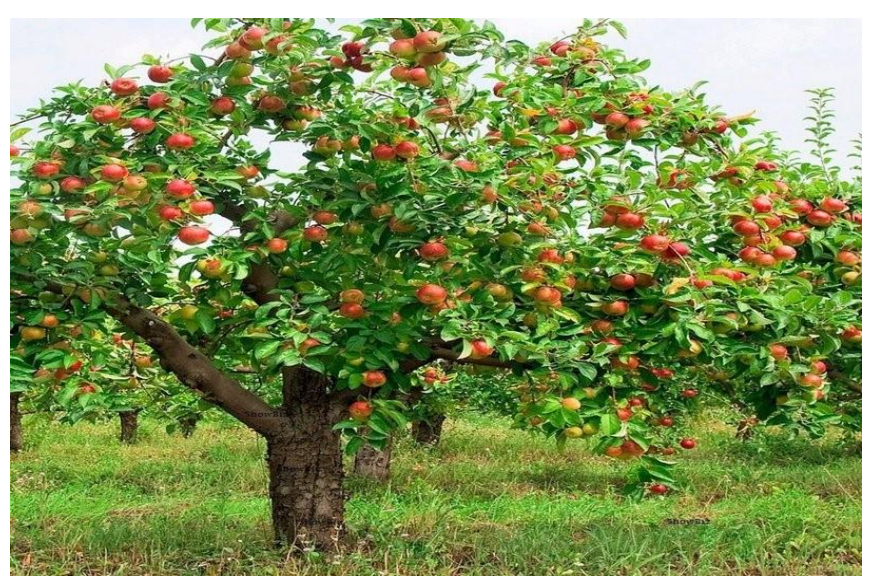

Şekil II

Şekil I' deki elma fidanı belli bir süre sonra şekil II' deki elma ağacı haline gelmiştir. Buna göre, elma fidanının büyüme ve gelişmesine etki eden faktörleri çizim yaparak gösteriniz. 


\section{Extended Abstract}

\section{Purpose of the Research}

In this study, a drawing technique was used to elicit students' thoughts about the factors that influence the growth and development of plants. The drawing is an open-ended technique that does not limit the student except for small delimiters, which can reveal many aspects of the narrative. Drawing is an activity that reflects the true content and behavior that is enjoyed by most people. The drawings show that students reflect their own learning, allowing teachers to plan learning as well (Atasoy, 2004). However, alternative ideas about students' science topics can also be revealed through drawing. The drawing can be used to identify students' misconceptions and can also be used as a class activity (Taber, 1999). The focus on the growth and development of plants is the fact that students are living in an environment where the natural environment is intense and a phenomenon of science that their families or their relatives have often observed in their daily lives because of their farming.

For this purpose, the following sub-problems were searched:

1) What are the factors that affect the growth and development of the plants in front of the relevant unit in the drawings of the students?

2) How did the factors affecting the growth and development of the plants reflect to the students' drawings after the relevant unit was processed?

3) 6. What are the erroneous and / or false consepts about the factors that affect the growth and development of plants by students?

\section{Method}

In this research, phenomenological method, which is one of the qualitative research methods, has been used. It is probed through drawings and interviews how students explain this phenomenon they have observed and experienced in their daily lives, starting from their own experience. The research was carried out with 23 students studying in the 6th grade in a state secondary school located in the province of Hendek, Sakarya province in the academic year of 2016-2017.

Prior to processing the "6.5.1.3 Describe factors that affect growth and development in plants and animals." in the plant and animal breeding, growth and development unit, students are asked to figure out the factors that affect the growth and development of plants. Then, during the period reserved for the acquisition, the subject is treated as required by the curriculum and students are asked to redraw. After both applications, the students were interviewed about the unexplained situations in the drawings. The obtained data is analyzed by content analysis and encoded by open coding.

\section{Findings}

In the first illustrations, it is seen that all 23 students who participated in the study included water in their drawings. Six of these students were painting rain as a water source, 13 were irrigation, and four students reflected both rain and irrigation. 20 students gave the sun the factors that affect the growth and development of plants. When we look at the other elements in the drawings, it is seen that the ( 16 frequently) gobbles are dense. Nine of these drawings are natural fertilizer, and seven are artificial fertilizer. In the drawing of 11 students, the soil was emphasized and placed in the drawings. Apart from these, two students painted oxygen and two students painted clean air. However, interviews with them have been coded separately because they are not found to be oxygen. In addition, the cells, germs, seeds, worms and human pictures in the drawings are confused as misconceptions. In interviews made with students (E3, E4, K1, K9) who have included people in their paintings, it has been understood that this visual refers to a person's interest in plants.

When the second drawings made after the topic is studied, it is seen that the water and the sun are still in the front lines. In the drawings, 11 of the students who have water show water as a source of rain, 6 irrigation, 2 painting both rain and irrigation. It is seen that the solar image has decreased in the second application. Twenty-three of the 23 students portrayed the sun. In the interviews, 
two students said that the plant benefited from vitamin $D$ in the sun. 14 students painted pictures emphasizing that fertilizer is necessary for the plant to grow, seven of them natural and the seventh of artificial fertilizer. Six students stated that plants can not survive without oxygen. When we looked at the other elements drawn, soil, cell, human, microbe, seed and root were drawn as they were in the first drawings. Unlike the first drawings, only one student stated that carbon dioxide is needed in order for plants to grow and develop. Examples of related drawings are given below.

In the context of the research, it has been observed that some ideas arising from wrong conception are included in the drawings of the students in the preliminary application or in the final application. These considerations are as follows:

- The idea that plants are benefiting from sunlight to get vitamin $D$

- For plants to grow and develop they need oxygen / clean air

- Thinking of the irrelevant factors that affect the growth and development of plants: cell, human, seed, germ, worm etc.

\section{Conclusions and Recommendations}

In the study, information about the factors affecting the growth and development of the 6th grade students was tried to be revealed with the drawing technique. The results obtained from the drawings made by the students before the relevant unit was processed show that the drawings of the students show that the water, the sun and the grenade are the front planes. The water source in all of the drawings of the students participating in the study is depicted as irrigation in some students in some students. It is noteworthy that students also include elements in their drawings caused by irrelevant or incorrect concepts such as soil, oxygen, worms, germs, and seeds. One of the most important factors in the growth and development of plants is carbon dioxide. However, the carbon dioxide that is not mentioned in any drawing before the subject is processed has been mentioned by only one student in the drawings after the subject has been processed. Within the scope of the research, it has been revealed that the students have two important misconceptions about the subject. One of them is that plants use to get vitamin D from the sun, and the other is that they need oxygen / clean air for their growth and development. With the drawing technique supported by the interviews, it was seen that the misconceptions of the students can be detected as much as the knowledge levels of the students.

It was observed that there was no change or development in the drawings of students after the related gains were processed except for a student. Since the research was not an experimental study, the lessons were done without extra practice, as the curriculum suggests. On the other hand, it was seen that students did not understand as much as the ability of the subject, that they could not make an association between the photosynthesis and the development of plants during the processing of the subject, and that the fallacy of the ones who went wrong continued.

As a result; it can be said that the drawing technique is a technique that can be easily used in the sense of the students' knowledge levels about their subject, their thoughts, the relations they have established among the concepts, and the misconceptions of the concepts. However, in order to illuminate elements that can not be reflected in the drawing, it is suggested to be supported by techniques such as interviewing, open-ended questions. During the instruction, it is also necessary for the students to be able to shape the lessons from the drawings before the subject is processed and to compare the drawings of the students with the drawings they have learned. Thus, it is considered that the drawings of the students will become the teaching materials and they will be able to control their learning through their own drawings. 